\title{
PEMANFAATAN BLANGKO OPINI UNTUK MENINGKATKAN PARTISIPASI MAHASISWA DALAM PEMBELAJARAN KOOPERATIF GROUP INVESTIGATION
}

\author{
Agus Budi Santosa \\ Dosen STKIP PGRI Trenggalek \\ e-mail : agusbudimu@yahoo.com
}

\begin{abstract}
:
Learning process is the logical essence of college education in affectingthe quality of output. Infact, the implementation of teaching and learning process in the classroom are faced on the problems that hinder the succes of the learning process. The troubling problem that occurs is the student low participation, which tends to just sit down, be quiet, and just listen without giving a response that is relevant to the learning process takes place.

The implementation Group Investigation of cooperative learning model wasdifficult to reach expectations. Researchers tried to use opinion form to solve the low of students participation on the discussion process of teaching and learning in STKIP PGRI Trenggalek.

The design of this research is classroom action research (Kemmis and Taggart design) that consist of three cycles, using constructivist approach with qualitative data. Data were collected by the method of observation, interviews and giving assignment. Then, it is analyzed descriptively (datareduction, datapresentation, and inference).

The results of data analysis showed that the use of opinion form can improve students' participation in cooperative learning on the subject of Belajar Pembelajaran, students are able to changetheir habits that tend to be passive to be students who has a willing to study hard and aware how to pose themselves and take part actively especially in delivering question, giving opinion and responsible to their duties of becoming students. The use of opinion form facilitate lecturerto motivate students to actively participate in the learning process because they are not only get an invitation and verbal motivation but also acts directly on the work.
\end{abstract}

\section{Keywords : Opinion Form, Students'Participation,Group Investigation of Cooperative Learning}

Pendahuluan

Salah satu tujuan pendidikan tinggi adalah berkembangnya potensi Mahasiswa agar menjadi manusia yang beriman dan bertakwa kepada Tuhan Yang Maha Esa dan berakhlak mulia, sehat, berilmu, cakap, kreatif, mandiri, terampil, kompeten, dan berbudaya untuk kepentingan bangsa; (UU 12 tahun 2012). Jika salah satu tujuan tersebut dapat diwujudkan melalui proses pembelajaran di perguruan tinggi, niscaya mahasiswa akan mampu sebagai sumberdaya manusia (SDM) yang memiliki kemampuan, keahlian, dan keterampilan yang dapat diandalkan untuk memasuki dunia kerja. Tentunya yang demikian menjadi cita-cita lembaga pendidikan tinggi untuk meningkatkan kualitas lulusannya dan akan menjadi bukti serta upaya nyata untuk meningkatkan daya saing bangsa.

Proses pembelajaran merupakan esensi logis dari penyelenggaraan pendidikan di perguruan tinggi yang berdampak terhadap kualitas out put. Tuntutan masyarakat terhadap efisiensi, produktivitas, efektivitas mutu, dan kegunaan hasil dalam penyelenggaraan proses pembelajaran di perguruan tinggi merupakan hal yang menjadi keharusan. Dikaitkan dengan perubahan mindset kurikulum 2013 yang menuntut partisipasi mahasiswa untuk lebih aktif dengan menggali potensi diri untuk tahu apa, tahu bagaimana dan tahu mengapa, maka tuntutan masyarakat tersebut adalah sesuatu yang sangat berat dalam proses pembelajaran. 
Pelaksanaan perkuliahan di kelas ternyata dihadapkan pada masalah yang menghambat keberhasilan proses pembelajaran tersebut. Masalah yang terjadi dan sangat merisaukan dosen adalah rendahnya partisipasi mahasiswa dalam proses kegiatan belajar mengajar di kelas. Dalam perkuliahan yang berlangsung selama ini, para mahasiswa cenderung hanya duduk, diam, dan sekedar mendengarkan tanpa memberikan respon yang relevan dengan materi kuliah. Gaya belajar mahasiswa dari sekolah masih mendominasimereka. Sikap menunggu perintah dari dosen, sikap menunggu ditegur lebih dahulu, dan sikap tidak acuh atau seenaknya saja masih mewarnai kehidupan mahasiswa.

Telah banyak inovasi pembelajaran yang dilakukan dosen untuk meningkatkan kualitas pembelajaran, khususnya inovasi pembelajaran dengan pendekatan kooperatif. Namun terkait dengan partisipasi dan dinamisasi mahasiswa, umumnya hasilnya kurang memuaskan.

Pendekatan kooperatif mendorong dan memberi kesempatan kepada mahasiswa untuk trampil berkomunikasi. Artinya, mahasiswa didorong untuk mampu menyatakan pendapat atau idenya dengan jelas, mendengarkan orang lain dan menanggapinya dengan tepat, meminta feedback serta mengajukan pertanyaan-pertanyaan dengan baik. Mahasiswa juga mampu membangun dan menjaga kepercayaan, terbuka untuk menerima dan memberi pendapat serta ide-idenya, mau berbagi informasi dan sumber, mau memberi dukungan pada orang lain. Mahasiswa juga mampu memimpin dan trampil mengelola kontroversi (managing controvercy) menjadi situasi problem solving, mengkritisi ide bukan persona orangnya. Pembelajaran kooperatif bertujuan untuk meningkatkan kerjasama akademik antar mahasiswa, membentuk hubungan positif, mengembangkan rasa percaya diri, serta meningkatkan kemampuan akademik.

Sebagai dosen di Lembaga Pendidikan Tenaga Kependidikan (LPTK), peneliti berusaha untuk melakukan treatment inovatif untuk meningkatkan partisipasi mahasiswa dalam pembelajaran kooperatif, dengan harapan mahasiswa semakin siap dengan dirinya sendiri sebagai calon pendidik di masa depan. Selama ini proses perkuliahan mata kuliah Belajar dan Pembelajaran sering dilaksanakan dengan pendekatan kooperatif, namun mahasiswa tidak menampakkan partisipasinya dalam proses kegiatan secara positif.

Di LPTKkhusunya pada mata kuliah pedagogik, pengalaman belajar merupakan sesuatu yang sama pentingnya dengan materi perkuliahan itu sendiri. Konsep learning to know, learning to do, learning to be dan learning to live together(Aunurrahman, 2009) pada mata kuliah Belajar dan Pembelajaran dengan pendekatan kooperatif diperlukan upaya meningkatkan partisipasi aktif dan dinamis terhadap proses pembelajaran. Blangko opini yang harus diisi oleh setiap mahasiswa, diperkirakan mampu meningkatkan partisipasi mahasiswa, karena mahasiswa harus memberikan tanggapan terhadap aspek-aspek proses diskusi yang telah berlangsung. Hal ini secara langsung merupakan tindak instropeksi diri mahasiswa untuk menilai proses dan secara tidak langsung dapat mengingatkan, mengajak dan memotivasi mahasiswa untuk harus bagaimana memposisikan diri serta berperan serta dalam proses secara ideal. Partisipasi belajar mahasiswa merupakan salah satu faktor yang berpengaruh terhadap keberhasilan belajar.

Penelitian ini bertujuan untuk : (1) Mengetahui apakah pemanfaatan blangko opini dapat meningkatkan partisipasi mahasiswa dalam pembelajaran kooperatif pada mata kuliah Belajar dan Pembelajaran. (2) Mengetahui pengaruh pemanfaatan blangko opini dapat meningkatkan partisipasi mahasiswa dalam pembelajaran kooperatif pada mata kuliah Belajar dan Pembelajaran.

Peneliti berharap agar hasil penelitian ini dapat bermanfaat : (1) Bagi mahasiswa untuk mempermudah pemahaman dan kompetensi terhadap materi mata kuliah Belajar dan Pembelajaran. (2) Bagi peneliti selaku dosen mata kuliah untuk meningkatkan efisiensi 
dan efektivitas pembelajaran di kelas. (3) Bagi program studi dapat dijadikan referensi dalam meningkatkan kualitas pembelajaran mata kuliah lain di kelas.

\section{Pendekatan dan Jenis Penelitian}

Penelitian ini menggunakan pendekatan konstruktivistik. Dalam penelitian ini mahasiswa diberi kebebasan untuk menciptakan makna dari apa yang dimiliki sebagai pengetahuan awal dan akan dihadapkan pada suatu permasalahan yang harus diamati, dipelajari, dicermati, dimodifikasi, diperbaharui, dan diubah oleh informasi baru yang didapat dalam proses yang pada akhirnya dapat meningkatkan partisipasi mahasiswa dalam kegiatan pembelajaran. Apabila partisipasi mahasiswa meningkat dalam kegiatan pembelajaran, maka akan meningkatkan pemahaman konsep materi pembelajaran, dan pada akhirnya dapat meningkatkan prestasi belajar. Untuk mengungkapkan proses pembelajaran tersebut peneliti mengumpulkan dan menangkap data selain dari isian blangko opini yang telah disiapkan, juga berupa fenomena dan bahasa verbal (kata-kata, kalimat, ungkapan).

Penelitian ini termasuk jenis penelitian tindakan (action research) dengan prinsip dasar (Wijaya Kusumah dan Dedi Dwitagama, 2009) : (1) Berkelanjutan secara siklutis; (2) Integral dari konteks yang diteliti; (3) Ilmiah dengan diagnosis masalah berdasar pada kejadian nyata; (4) Motivasi yang tumbuh dari diri peneliti; (5) Memiliki lingkup masalah pembelajaran di dalam maupun di luar kelas.

\section{Lokasi Penelitian}

Penelitian ini berlokasi di Program Studi Pendidikan Bahasa dan Sastra Indonesia, Sekolah Tinggi Keguruan dan Ilmu Pendidikan Persatuan Guru Republik Indonesia (STKIP PGRI) Trenggalek

\section{Desain dan Prosedur Penelitian}

Langkah-langkah dan desain penelitian mengikuti prinsip dasar yang dikemukakan oleh Kemmis dan Taggart (Wijaya Kusumah dan Dedi Dwitagama, 2009). Prosedur dan langkah-langkah penelitian mengikuti prinsip dasar yang berlaku dalam penelitian tindakan, terdiri dari empat tahap yang merupakan proses daur ulang (siklus) mulai dari tahap perencanaan, pelaksanaan tindakan, observasi dan refleksi serta diikuti denganperencanaan ulang jika diperlukan.

Penelitian ini dilaksanakan dalam tiga siklus. Langkah awal yang dilakukan peneliti adalah menyusun silabus, rencana pembelajaran dan kontrak perkuliahan mata kuliah Belajar dan Pembelajaran. Langkah administrasi tersebut disampaikan secara terbuka kepada mahasiswa. Selanjutnya peneliti menyusun langkah-langkah tindakan untuk melaksanakan penelitian sesuai dengan siklus yang dijalankan.

\section{Data dan Sumber Data}

Jenis data yang dikumpulkan adalah data kualitatif yang berupa hasil isian blangko opini dan observasi tentang jalannya proses pembelajaran: respon mahasiswa terhadap metode pembelajaran; aktivitas mahasiswa. Di samping itu, dilengkapi data pendukung diambil data kuantitatif dari hasil tes sebelum dan sesudah dilaksanakannya tindakan. Catatan kehadiran, kejadian khusus mahasiswa, dan data lapangan lain yang berkaitan dengan pelaksanaan tindakan juga dikumpulkan. Sumber data yang sekaligus sebagai subjek penelitian adalah mahasiswa Program Studi Pendidikan Bahasa dan Sastra Indonesia, STKIP PGRI Trenggalek, semester gasal tahun akademik 2013/2014 mata kuliah Belajar dan Pembelajaran.

\section{Teknik Pengumpulan Data}


Pengumpulan data dalam penelitian ini dilakukan dengan menggunakan teknik sebagai berikut: (1) Observasi, dilakukan oleh dosen sejawat terhadap proses pembelajaran untuk mengetahui keaktifan mahasiswa bertanya dan berpendapat, kesungguhan mengerjakan tugas, serta tingkat kehadiran mahasiswa. Teknik observasi dilakukan dengan menggunakan alat berupa daftar cek (ceck list);(2) Wawancara, dilakukan oleh peneliti terhadap mahasiswa, untuk memperoleh gambaran yang mendalam tentang pemahaman mahasiswa, kesulitan-kesulitan yang dialami mahasiswa baik pada tingkat pemahaman konsep, maupun suasana pembelajaran di kelas. Dalam melakukan wawancara ini peneliti menggunakan alat berupa pedoman wawancara; (3) Penugasan, dilakukan untuk mendapatkan data tentang kemampuan mahasiswa dalam penguasaan konsep guna mengukur pemahaman pada setiap siklus, mahasiswa diberikan tugas-tugas terstruktur. Alat yang digunakan untuk teknik ini adalah pedoman tugas.

\section{Analisis Data}

Data yang berhasil dikumpulkan melalui observasi, interview dan field notedianalisis dengan menggunakan metode alir (Sugiono, 2008). Data kualitatif dianalisis dengan statistik deskriptif. Secara jelas analisis data terdiri dari tiga tahapan kegiatan yaitu: (1) Reduksi Data, (2) Penyajian Data, dan (3) Penyimpulan.

\section{Keabsahan Data}

Pengecekan keabsahan data dilakukan dengan teknik trianggulasi sumber data. Trianggulasi merupakan pemeriksaan data yang memanfaatkan sesuatu yang lain di luar data itu untuk keperluan pengecekan atau sebagai pembanding terhadap data tersebut (Sugiono, 2008). Diskusi, tukar pikiran, dan musyawarah dilaksanakan antara peneliti dengan teman sejawat sebagai pengamat, untuk menarik kesimpulan yang tepat terhadap data yang telah diperoleh.

\section{Hasil Penelitian dan Pembahasan Hasil Tindakan pada Siklus Pertama Kehadiran} 1 berikut :

Kehadiran mahasiswa pada perkuliahan selama siklus pertama sebagaimana tabel

\begin{tabular}{lcc}
\multicolumn{3}{l}{ Tabel 1 : Kehadiran Mahasiswa } \\
\hline $\begin{array}{l}\text { Perte } \\
\text { muan }\end{array}$ & $\begin{array}{c}\text { Jumlah } \\
\text { Mahasiswa } \\
\text { Hadir }\end{array}$ & Prosentase (\%) \\
\hline Pertam & 30 & $100 \%$ \\
a & 30 & $100 \%$ \\
Kedua & 30 & $96,67 \%$ \\
Ketiga & 29 & $100 \%$ \\
Keemp & 30 & \\
at & & $93,33 \%$ \\
Kelima & 28 & \\
\hline
\end{tabular}

Kehadiran mahasiswa dalam kuliah mulai pertemuan pertama sampai dengan kelima masih dalam kategori normal yaitu rata-rata selama lima pertemuan kehadiran mahasiswa sejumlah 29,4 mahasiswa (98\%) dari 30 mahasiswa dalam satu kelas.

\section{Partisipasi Bertanya}


Proses pembelajaran pada siklus pertama dilakukan dengan metode ceramah, tanya jawab, dan brain storming, dilakukan pada pertemuan kesatu sampai dengan keenam. Selama perkuliahan berlangsung mahasiswa diberi kesempatan untuk bertanya mengenai topik perkuliahan. Hanya sebagian kecil yang aktif mengajukan pertanyaan dengan ratarata mahasiswa yang aktif bertanya sebesar 1,6 mahasiswa. Sebaran keaktifan bertanya mahasiswa pada saat perkuliahan siklus pertama berlangsung, sebagaimana tabel 2 berikut:

Tabel 2. Partisipasi Bertanya

\begin{tabular}{lcc}
\hline Pertemuan & $\begin{array}{c}\text { Jumlah Mahasiswa } \\
\text { Bertanya }\end{array}$ & $\begin{array}{c}\text { Prosentase } \\
(\%)\end{array}$ \\
\hline Pertama & 1 & $3,33 \%$ \\
Kedua & 0 & $0 \%$ \\
Ketiga & 2 & $6,9 \%$ \\
Keempat & 3 & $10 \%$ \\
Kelima & 2 & $7,14 \%$ \\
\hline
\end{tabular}

Pada pertemuan pertama hanya 1 mahasiswa $(3,33 \%)$ yang mengajukan pertanyaan, dan pertanyaannyapun tidak terkait dengan materi atau topik perkuliahan, dan bahkan di pertemuan kedua tidak ada mahasiswa aktif bertanya (0\%). Pada pertemuan ketiga terdapat 2 mahasiswa $(6,9 \%)$ dari 29 mahasiswa hadir dan meningkat pada pertemuan keempat menjadi 3 mahasiswa $(10 \%)$ dari 30 mahasiswa hadir dengan pertanyaan mulai menuju substansi perkuliahan. Pada pertemuan kelima hanya terdapat 2 mahasiswa $(7,14 \%)$ dari 28 mahasiswa hadir yang aktif bertanya yang salah satunya merupakan mahasiswa yang sama saat pertemuan keempat. Berdasarkan data tersebut membuktikan rendahnyaminat terhadap mata kuliah Belajar dan Pembelajaran.

\section{Partisipasi Berpendapat dan Menjawab}

Keaktifan berpendapat ini dilihat dari partisipasi mahasiswa untuk mengemukakan pendapat dan menjawab pertanyaan dosen selama kuliah berlangsung, diketahui rata-rata selama kuliah berlangsung sebesar 1,2 mahasiswa. Hasil kektifan berpendapat sebagaimana tabel 3 berikut :

Tabel 3. Partisipasi Berpendapat dan Menjawab

\begin{tabular}{|c|c|c|}
\hline Pertemuan & $\begin{array}{c}\text { Jumlah } \\
\text { Mahasiswa } \\
\text { Berpendap } \\
\text { at dan } \\
\text { Menjawab }\end{array}$ & Prosentase $(\%)$ \\
\hline Pertama & 1 & $3,33 \%$ \\
\hline Kedua & 2 & $6,66 \%$ \\
\hline Ketiga & 0 & $0 \%$ \\
\hline Keempat & 1 & $3,33 \%$ \\
\hline Kelima & 2 & $7,14 \%$ \\
\hline
\end{tabular}

Pada pertemuan pertama terdapat satu $(3,33 \%)$ mahasiswadari 30 mahasiswa hadir yang tertarik untuk berpendapat. Pertemuan kedua terdapat dua $(6,66 \%)$ mahasiswa dari 30 mahasiswa hadir yang berani menjawab pertanyaan dosen, namun pada pertemuan ketiga tidak ada satupun mahasiswa yang menjawab pertanyaan dosen dan mengajukan pendapatnya.Pada pertemuan keempat terdapat satu $(3,33 \%)$ mahasiswa dari 30 mahasiswa hadir yang menjawab pertanyaan dosen dan terdapat dua $(7,14 \%)$ mahasiswa dari 28 mahasiswa hadir pada pertemuan kelima. Pada pertemuan kedua sampai dengan kelima dari 5 pendapat dan jawaban pertanyaan hanya dilakukan oleh dua mahasiswa yang sama. Kondisi ini menunjukkan bahwa ketertarikan mahasiswa untuk mengajukan pendapat atau aktif mengemukakan gagasannya dan menjawab pertanyaan dosen, ternyata sangat rendah.

\section{Partisipasi Mengerjakan Tugas}


Keaktifan mengerjakan tugas merupakan tugas individu, diukur dari ketepatan waktu mengumpulkan dan kualitas tugas yang dikerjakan mahasiswa. Selama lima pertemuan pada siklus pertama dilakukan penugasan sebanyak dua kali, yaitu pada pertemuan ketiga dan kelima. Tugus dikumpulkan berdasarkan komitmen yaitu pada pertemuan keempat dan keenam. Hasil keaktifan mengerjakan tugas sebagaimana tabel 4 berikut :

Tabel 4. PartisipasiPengerjakan Tugas

\begin{tabular}{lcccccccccc}
\hline \multirow{3}{*}{ Tugas } & \multicolumn{3}{c}{ Waktu Pengumpulan } & \multicolumn{5}{c}{ Kualitas Tugas } \\
\cline { 2 - 13 } & \multicolumn{2}{c}{ Tepat Waktu } & \multicolumn{2}{c}{ Tidak Tepat } & \multicolumn{2}{c}{ Tinggi } & \multicolumn{2}{c}{ Sedang } & \multicolumn{2}{c}{ Rendah } \\
\cline { 2 - 13 } & Jml. & $\%$ & Jml. & $\%$ & Jml. & $\%$ & Jml. & $\%$ & Jml. & $\%$ \\
\hline Pertama & 28 & 93,33 & 2 & 6,67 & 8 & 26,67 & 18 & 60 & 4 & 13,33 \\
Kedua & 26 & 86,67 & 4 & 13,33 & 12 & 40 & 12 & 40 & 6 & 20 \\
\hline
\end{tabular}

Ketepatan waktu dalam mengumpulkan tugas pertama, sebenarnya sudah menunjukkan kedisiplinan yaitu 28 mahasiswa $(93,33 \%)$ sudah tepat waktu. Namun terjadi penurunan pada tugas kedua menjadi 26 mahasiswa $(86,67 \%)$ tepat waktu. Sedangkan kualitas tugas belum menunjukkan hasil yang memuaskan.Hal ini berarti kesungguhan dan keseriusan mahasiswa masih cukup rendah. Meskipun ada peningkatan kualitas tugas, yaitu pada kualitas tugas tinggi meningkat dari 8 mahasiswa $(26,67 \%)$ pada tugas pertama menjadi 12 hahasiswa (40\%) pada tugas kedua. Namun pada kualitas rendah jumlah mahasiswa justru meningkat, yaitu 4 mahasiswa (13,33\%) menjadi 6 mahasiswa (20\%).

\section{Hasil Tindakan pada Siklus Kedua}

Proses pembelajaran pada siklus kedua, dilaksanakan dengan menerapkan pendekataan kooperatif Group Investigation. Pendekatan ini diterapkan berdasarkan hasil siklus pertama yang menunjukkan hasil yang tidak positif bahkan memprihatinkan terutama dalam hal keaktifan dan partisipasi mahasiswa dalam proses pembelajaran. Model pembelajaran Group Investigationmemiliki ciri-ciri(Depdiknas, Dirjendikti, Direktorat Ketenagaan, 2007) : berpusat pada siswa, pembelajaran yang dilakukan membuat suasana saling bekerjasama dan berinteraksi memadukan berbagai ide dan pendapat, mahasiswa dilatih untuk memiliki kemampuan yang baik dalam berkomunikasi, semua kelompok menyajikan suatu presentasi yang menarik dari berbagai topik yang telah dipelajari,suasana belajar terasa lebih efektif, kerjasama kelompok dalam pembelajaran ini dapat membangkitkan semangat mahasiswa untuk memiliki keberanian dalam mengemukakan pendapat dan berbagi informasi dengan teman lainnya dalam membahas materi pembelajaran.

Dengan ciri model pembelajaran Group Investigationtersebut siklus kedua diyakini memiliki perubahan yang positif dan signifikan untuk meningkatkan partisipasi mahasiswa dalam memahami konsep-konsep materi kuliah Belajar dan Pembelajaran dengan membagi kedalam kelompok-kelompok. Siklus kedua berlangsungpada pertemuan ketujuhsampai dengan kesepuluh. Dari 30 mahasiswa dibagi menjadi 4 kelompok dan setiap pertemuan terdapat satu kelompok harus mempresentasikan makalahnya. Dalam hal pemberian umpan balik, tidak dibatasi termin dan mengalir secara alami sesuai dengan partisipasi audien serta alokasi waktu yang ditetapkan.

Penyampaian materi kuliah dengan menerapkan model pembelajaran Group Investigation, diketahui hasil tindakan pada siklus kedua ini adalah sebagai berikut :

\section{Kehadiran}

Kehadiran mahasiswa pada perkuliahan selama siklus keduasebagaimana tabel 5 berikut : 
Tabel 5 : Kehadiran Mahasiswa

\begin{tabular}{lcc}
\hline \multicolumn{1}{c}{ Pertemuan } & Jumlah Mahasiswa Hadir & Prosentase (\%) \\
\hline Ketujuh & 29 & $96,67 \%$ \\
Kedelapan & 30 & $100 \%$ \\
Kesembilan & 28 & $93,33 \%$ \\
Kesepuluh & 29 & $96,67 \%$ \\
\hline
\end{tabular}

Kehadiran mahasiswa dalam kuliah siklus kedua rata-rata selama empat pertemuan, kehadiran mahasiswa sejumlah 29 mahasiswa (96,67\%).

\section{Partisipasi Bertanya}

Proses pembelajaran pada siklus kedua, sebaran keaktifan bertanya mahasiswa sebagai audien pada saat diskusi berlangsung, sebagaimana tabel 6 berikut :

Tabel 6 :Partisipasi Bertanya

\begin{tabular}{lcc}
\hline \multicolumn{1}{c}{ Pertemuan } & Jumlah Mahasiswa Bertanya & Prosentase (\%) \\
\hline Ketujuh & 5 & $23,81 \%$ \\
Kedelapan & 5 & $22,72 \%$ \\
Kesembilan & 6 & $28,57 \%$ \\
Kesepuluh & 5 & $23,81 \%$ \\
\hline
\end{tabular}

Diskusi pada semua pertemuan berlangsung dua termin, dan pada pertemuan ketujuhterdapat 5mahasiswa $(23,81 \%)$ yang mengajukan pertanyaan dari 21 mahasiswa sebagai audien.Pertemuan kedelapan tidak ada perubahan, hanya 5 mahasiswa $(22,72 \%)$ dari 22 mahasiswa sebagai audien. Pada pertemuan kesesembilan terdapat 6 mahasiswa $(28,57 \%)$ dari 21 mahasiswa sebagai audien dan pada pertemuan kesepuluhterdapat 5 mahasiswa $(23,81 \%)$ dari 21 mahasiswa sebagai audien. Berdasarkan data tersebut sudah menunjukkan peningkatanminat terhadap mata kuliah Belajar dan Pembelajaran. Namun pertanyaan yang muncul masih bersifat konsep/pengetahuan saja dan belum menyentuh pada permasalahan praktis aplikatif yang lebih komplek.

\section{Partisipasi Berpendapat}

Keaktifan berpendapat ini dilihat dari partisipasi mahasiswa sebagai audien untuk mengemukakan pendapat selama diskusi berlangsung, diketahui sebagaimana tabel 7 berikut

Tabel 7. Partisipasi Berpendapat

\begin{tabular}{lcc}
\hline Pertemuan & $\begin{array}{c}\text { Jumlah Mahasiswa } \\
\text { Berpendapat }\end{array}$ & Prosentase $(\%)$ \\
\hline Ketujuh & 2 & $9,52 \%$ \\
Kedelapan & 4 & $18,18 \%$ \\
Kesembilan & 2 & $9,52 \%$ \\
Kesepuluh & 3 & $14,29 \%$ \\
\hline
\end{tabular}

Pada pertemuan ketujuhterdapat 2 mahasiswa (9,52 \%) dari 21 mahasiswa sebagai audien yang ikut berpendapat menyampaikan gagasannya. Pertemuan kedelapan tidak ada perubahan, hanya 4 mahasiswa $(18,18 \%)$ dari 22 mahasiswa sebagai audien yang ikut berpendapat menyampaikan gagasannya. Pada pertemuan kesesembilan terdapat 2 mahasiswa $(14,29 \%)$ dari 21 mahasiswa sebagai audien dan pada pertemuan kesepuluh terdapat 3 mahasiswa $(14,29 \%)$ dari 21 mahasiswa sebagai audien yang ikut berpendapat 
menyampaikan gagasannya. Berdasarkan data tersebut sudah menunjukkan peningkatan minat terhadap mata kuliah Belajar dan Pembelajaran. Kondisi ini menunjukkan bahwa ketertarikan mahasiswa untuk mengajukan pendapat atau aktif mengemukakan gagasannya mulai muncul tetapi masih cukup rendah. Berdasarkan pengamatan peneliti terdapat satu mahasiswa berani menyampaikan gagasannya tiga dari empat kegiatan diskusi.

\section{Partisipasi Mengerjakan Tugas}

Keaktifan mengerjakan tugas, diukur dari ketepatan waktu dankualitas tugas kelompok berupa kelengkapan dan kedalam kajian makalah yang disajikan dalam diskusi. Makalah disampaikan ke dosen dan kelompok audien berdasarkan komitmen yaitu selambatlambatnya tiga hari sebelum pelaksanaan diskusi. Hasil keaktifan mengerjakan tugas sebagaimana tabel 8 berikut :

Tabel 8. PartisipasiPengerjakan Tugas

\begin{tabular}{lcccccccccc}
\hline \multirow{2}{*}{ Tugas } & \multicolumn{3}{c}{ Waktu Penyampaian } & \multicolumn{5}{c}{ Kualitas Tugas } \\
\cline { 2 - 11 } & \multicolumn{2}{c}{ Tepat Waktu } & \multicolumn{2}{c}{ Tidak Tepat } & \multicolumn{2}{c}{ Tinggi } & \multicolumn{2}{c}{ Sedang } & \multicolumn{2}{c}{ Rendah } \\
\cline { 2 - 11 } & Jml. & $\%$ & Jml. & $\%$ & Jml. & $\%$ & Jml. & $\%$ & Jml. & $\%$ \\
\hline $\begin{array}{l}\text { Penyusunan } \\
\text { Mkalah }\end{array}$ & 3 & $75 \%$ & 1 & $25 \%$ & 2 & 50 & 2 & 50 & - & - \\
\hline
\end{tabular}

Ketepatan waktu dalam mengumpulkan tugas penyusunan makalah, terdapat tiga kelompok (75\%) sudah tepat waktu dan satu kelompok (25\%) tidak tepat waktu. Sedangkan kualitas tugas belum menunjukkan kesungguhan dan keseriusan, meskipun tidak terdapat kelompok dengan kualitas rendah, namun hanya 2 kelompok (50\%) mampu menyelesaikn tugas dengan kualifikasi tinggi dan sisanya 2 kelompok (50\%) masih tergolong sedang.

\section{Hasil Tindakan pada Siklus Ketiga}

Pada siklus ketiga ini proses pembelajaran menggunakan pendekatan seperti pada siklus kedua. Treatment siklus ketiga dengan memberikan blangko opini yang harus diisi oleh setiap mahasiswa (audien) terhadap jalannya diskusi. Opini terkait dengan kualitas tampilan media power point (LCD Projector), kekompakan kelompok, dan ketepatan materi pembahasan yang dilakukan oleh penyaji baik terhadap makalah maupun dalam memberikan jawaban atau tanggapan dari audien. Blangko opini dikumpulkan setiap selesai diskusi dari masing-masing kelompok. Dengan memanfaatkan blangko opini dalam penyampaian materi kuliah, maka hasil tindakan pada siklus ketiga ini adalah sebagai berikut:

\section{Kehadiran} 9berikut :

Kehadiran mahasiswa pada perkuliahan selama siklus ketigasebagaimana tabel

Tabel 9 : Kehadiran Mahasiswa

\begin{tabular}{lcc}
\hline \multicolumn{1}{c}{ Pertemuan } & Jumlah Mahasiswa Hadir & Prosentase (\%) \\
\hline Kesebelas & 29 & $96,67 \%$ \\
Keduabelas & 29 & $96,67 \%$ \\
Ketigabelas & 30 & $100 \%$ \\
Keempatbelas & 29 & $96,67 \%$ \\
\hline
\end{tabular}

Kehadiran mahasiswa dalam kuliah siklus ketiga rata-rata selama empat pertemuan, kehadiran mahasiswa sejumlah 29,25 mahasiswa $(97,5 \%)$. 


\section{Partisipasi Bertanya}

Proses pembelajaran pada siklus ketiga, sebaran keaktifan bertanya mahasiswa sebagai audien pada saat diskusi berlangsung, sebagaimana tabel 10 berikut :

Tabel 10 :Partisipasi Bertanya

\begin{tabular}{lcc}
\hline \multicolumn{1}{c}{ Pertemuan } & Jumlah Mahasiswa Bertanya & Prosentase $(\%)$ \\
\hline Kesebelas & 6 & $28,57 \%$ \\
\hline Keduabelas & 8 & $38,1 \%$ \\
\hline Ketigabelas & 9 & $39,13 \%$ \\
\hline Keempatbelas & 9 & $40,91 \%$ \\
\hline
\end{tabular}

Diskusi pada pertemuan kesebelas berlangsung dua termin sedangkan pertemuan keduabelas sampai dengan keempatbelas berlangsung tiga termin. Pada pertemuan kesebelasterdapat 6mahasiswa $(28,57 \%)$ yang mengajukan pertanyaan dari 21 mahasiswa sebagai audien. Pertemuan keduabelas terdapat 8mahasiswa $(38,1 \%)$ dari 21 mahasiswa sebagai audien. Pada pertemuan ketigabelas dan empatbelas masing-masing terdapat 9 mahasiswa $(39,13 \%)$ dari 23 mahasiswa sebagai audien dan $(40,91 \%)$ dari 22 mahasiswa sebagai audien.

Berdasarkan data tersebut sudah menunjukkan peningkatan minat terhadap mata kuliah Belajar dan Pembelajaran. Pertanyaan yang muncul sudah masuk pada permasalahan praktis aplikatif yang lebih komplek, meskipun masih terdapat lima pertanyaan yang sifatnya meminta penjelasan kembali. Hal yang menggembirakan adalah pada diskusi pertemuan ke tigabelas dan empatbelas, mulai tumbuh keberanian mahasiswa audien untuk bertanya, namun karena waktu dan antusiasnya berbagai tanggapan, terdapat duabelas mahasiswa audien yang tidak terlayani dalam sesi umpan balik.

\section{Partisipasi Berpendapat}

Partisipasi mahasiswa sebagai audien untuk mengemukakan pendapat selama diskusi berlangsung, diketahui sebagaimana tabel 11 berikut :

Tabel 11. Partisipasi Berpendapat

\begin{tabular}{lcc}
\hline \multicolumn{1}{c}{ Pertemuan } & Jumlah Mahasiswa Berpendapat & Prosentase (\%) \\
\hline Kesebelas & 4 & $19,05 \%$ \\
Keduabelas & 6 & $28,57 \%$ \\
Ketigabelas & 6 & $26,09 \%$ \\
Keempatbelas & 8 & $36,36 \%$ \\
\hline
\end{tabular}

Pada pertemuan kesebelasterdapat 4mahasiswa (19,05\%) dari 21 mahasiswa sebagai audien yang ikut berpendapat menyampaikan gagasannya. Pertemuan kedubelasterdapat 6mahasiswa $(28,57 \%)$ dari 21 mahasiswa sebagai audien yang ikut berpendapat menyampaikan gagasannya. Pada pertemuan ketigabelas terdapat 6 mahasiswa (26,09\%) dari 23 mahasiswa sebagai audien dan pada pertemuan keempatbelas terdapat 8 mahasiswa $(36,36$ $\%)$ dari 22 mahasiswa sebagai audien yang ikut berpendapat menyampaikan gagasannya. Berdasarkan data tersebut sudah menunjukkan peningkatan minat terhadap mata kuliah Belajar dan Pembelajaran. Kondisi ini menunjukkan bahwa ketertarikan mahasiswa untuk mengajukan pendapat atau aktif mengemukakan gagasannya sudah tumbuh signifikan.

\section{Partisipasi Mengerjakan Tugas}

Keaktifan mengerjakan tugas, diukur dari ketepatan waktu dankualitas tugas kelompok berupa kelengkapan dan kedalam kajian makalah yang disajikan dalam diskusi. 
Makalah disampaikan ke dosen dan kelompok audien berdasarkan komitmen yaitu selambatlambatnya tiga hari sebelum pelaksanaan diskusi. Hasil keaktifan mengerjakan tugas sebagaimana tabel 12 berikut :

Tabel 12. Partisipasi Pengerjakan Tugas

\begin{tabular}{lcccccccccc}
\hline \multirow{3}{*}{ Tugas } & \multicolumn{3}{c}{ Waktu Penyampaian } & \multicolumn{5}{c}{ Kualitas Tugas } \\
\cline { 2 - 10 } & \multicolumn{2}{c}{ Tepat Waktu } & \multicolumn{2}{c}{ Tidak Tepat } & \multicolumn{2}{c}{ Tinggi } & \multicolumn{2}{c}{ Sedang } & \multicolumn{2}{c}{ Rendah } \\
\cline { 2 - 10 } & Jml. & $\%$ & Jml. & $\%$ & Jml. & $\%$ & Jml. & $\%$ & Jml. & $\%$ \\
\hline $\begin{array}{l}\text { Penyusunan } \\
\text { Mkalah }\end{array}$ & 4 & $100 \%$ & - & - & 3 & $75 \%$ & 1 & $25 \%$ & - & - \\
\hline
\end{tabular}

Semua kelompok (100\%) telah mentaati komitmen waktu pengumpulan tugas penyusunan makalah. Sedangkan kualitas tugas kategori tinggi menunjukkan kesungguhan dan keseriusan terdapat 3 kelompok (75\%), dan 1 kelompok (25\%) masih tergolong sedang.

\section{Monitoring}

Kegiatan monitoring yang dilakukan pada siklus pertama sampai dengan siklus ketiga terhadap keaktifan kehadiran, partisipasi untuk aktif bertanya, partisipasi untuk berpendapat dan menjawab, keaktifan mengerjakan tugas yang meliputi ketepatan waktu mengumpulkan dan kualitas hasil tugas pada saat perkuliahan berlangsung.

\section{Refleksi}

Berdasarkan hasil pengamatan dan penilaian terhadap tugas mahasiswa pada siklus pertama sampai dengan siklus ketiga, dengan menerapkan pembelajaran kooperatif dengan treatment blangko opini, peneliti melaksanakan refleksidan menunjukkan hal-hal sebagai berikut : (1) Proses pembelajaran di kelas berlangsung dinamis ditandai dengan partisipasi mahasiswa dalam menyampaikan pertanyaan dan pendapat semakin meningkat. (2) Mampu mendorong mahasiswa untuk berpartisipasi aktif dalam menyampaikan ide-ide baru berkaitan masalah praktis aplikatif dalam belajar dan pembelajaran yang berkembang di dunia pendidikan. (3) Dalam hal penguasaan terhadap materi kuliah cenderung semakin baik. Hal ini terbukti dari hasil wawancara terhadap mahasiswa yang mengaku bahwa dengan adanya blangko opini yang harus diisi, mahasiswa lebih tertantang dan menyadari pentingnya berperan serta dalam proses diskusi sebagai usaha pengembangan potensi diri. (4) Meskipun terkesan ada upaya pemaksaan dari dosen untuk mengisi blangko opini, pada akhirnya mahasiswa menyadari pentingnya berpartisipasi aktif dengan belajar menilai dan memberi tanggapan terhadap proses yang harus diamati, dipelajari dan dicermati yang secara tidak langsung menumbuhkan tanggung jawab terhadap dirinya untuk berprestasi.

\section{Pembahasan}

Hasil analisis setiap siklus tindakan menunjukkan bahwa dengan memanfaatkan blangko opini pada model pembelajaran kooperatif mampu meningkatkan partisipasi mahasiswa pada saat proses kegiatan belajar mengajar di kelas. Kondisi yang merisaukan dosen tentang rendahnya partisipasi mahasiswa dalam proses kegiatan belajar mengajar di kelas terbukti bisa berangsur-angsur teratasi. Mahasiswa mulai aktif memberikan respon yang relevan dan tidak sekedar duduk mendengarkan.

Dengan blangko opini yang disiapkan dosen, membuat mahasiswa terlecut dan ditantang untuk mengeksploitasi dirinya, karena suka atau tidak suka, terpaksa atau dengan kesadaran, bahwa tugas untuk menilai dan memberikan tanggapan terhadap jalannya diskusi harus dijalankan. Hal ini secara tidak langsung dosen mengajak dan memotivasi mahasiswa untuk berubah, serta berusaha membawa mahasiswa untuk harus bagaimana memposisikan 
diri serta berperan serta dalam proses secara ideal. Mahasiswa harus meninggalkan kebiasaan saat di sekolah yang cenderung menunggu perintah, menjadi kebiasaan untuk berpikir keras, mengeluarkan pendapatdan idenya, serta bebas dalam mengkaji serta mengeksplorasi topiktopik penting dalam pembahasan materi perkuliahan.

Dengan demikian penelitian ini sejalan dengan tujuan pendidikan tinggi dalam mengembangkan potensi mahasiswa agar menjadi manusia yang berilmu, cakap, kreatif, mandiri, terampil dan kompeten. Hal ini juga memberikan bekal kepada mahasiswasebagai calon pendidik bahwa di dunia pendidikan khususnya LPTK, pengalaman belajar sama pentingnya dengan materi perkuliahan.

\section{Penutup}

Simpulan

Bahwa pemanfaatan blangko opini dapat meningkatkan partisipasi mahasiswa dalam pembelajaran kooperatif pada mata kuliah Belajar dan Pembelajaran.

Pemanfaatan blangko opini berpengaruh dalam meningkatkan partisipasi mahasiswa dalam pembelajaran kooperatif pada mata kuliah Belajar dan Pembelajaran, yaitu mampu merubah kebiasaan mahasiswa yang cenderung pasif, menjadi mahasiswa yang mau berusaha membawa dirinya untuk harus bagaimana memposisikan diri serta berperan serta dalam proses secara ideal, terutama dalam hal keaktifan bertanya, mengajukan pendapat atau gagasan dan bertanggung jawab terhadap tugas-tugasnya sebagai mahasiswa.

Blangko opini memudahkan dosen memotivasi mahasiswa untuk aktif berpartisipasi dalam proses belajar karena mahasiswa tidak hanya mendapatkan ajakan dan motivasi verbal saja, melainkan langsung pada tindak berkarya.

\section{Saran}

Mengingat mahasiswa di STKIP PGRI Trenggalek memiliki latar belakang sosial budaya dan motivasi yang heterogen, dosen harus terus memberikan penghargaan kepada setiap upaya positif mahasiswa guna meningkatkan dan menumbuh kembangkan rasa percaya diri mahasiswa.

Mahasiswa harus mempersiapkan diri untuk mengembangkan potensi diri dengan memanfaatkan perpustakaan kampus dan familier terhadap teknologi sehingga mampu mengakses materi perkuliahan lebih luas.

Dosen harus lebih bijak terhadap mahasiswa yang motivasi dirinya rendah, karena heterogennya latar belakang kualitas input.

\section{Daftar Rujukan}

Abdorrakhman Ginting, Esensi Praktis Belajar dan Pembelajaran, Bandung, Humaniora. Aunurrahman, 2009, Belajar dan Pembelajaran, Bandung, Alfabeta.

Depdiknas, Dirjendikti, Direktorat Ketenagaan, 2007, Pembelajaran Inovatif dan Partisipatif, Bahan Workshop.

Dimyati dan Mudjiono, 2006, Belajar dan Pembelajaran, Jakarta, PT Rineka Cipta.

Mahmud, 2011, Metode Penelitian Pendidikan, Bandung, Pustaka Setia.

Mulyasa. E., 2009, Praktik Penelitian Tindakan Kelas, Bandung, PT Rermaja Rosdakarya.

Sugiono, 2008, Metode Penelitian Kuantitatif Kualitatif dan $R \&$ D, Alfabeta, Bandung.

Undang-Undang Republik Indonesia Nomor : 12 tahun 2012, tentang Pendidikan Tinggi

Usman Husaini, 2006, Manajemen Teori, Praktik, dan Riset Pendidikan, Bumi Aksara, Jakarta. 
Wijaya Kusumah dan Dedy Dwitagama, Mengenal Penelitian Tindakan Kelas, Jakarta, PT Indeks. 